
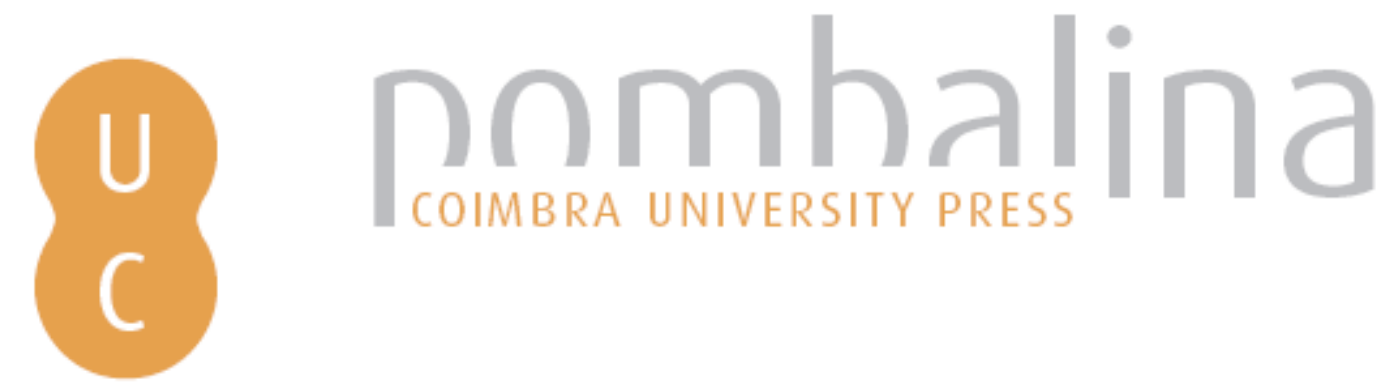

\title{
Iconografia e ideologia política: a representação da missão de Triptólemo e de cenas de família na pintura de vasos áticos
}
Autor(es):
Ferreira, Luísa de Nazaré
Publicado por: Imprensa da Universidade de Coimbra
URL
persistente:
URI:http://hdl.handle.net/10316.2/45153
DOI:
DOI:https://doi.org/10.14195/978-989-26-1679-7_11
Accessed : $\quad$ 26-Apr-2023 15:49:54

A navegação consulta e descarregamento dos títulos inseridos nas Bibliotecas Digitais UC Digitalis, UC Pombalina e UC Impactum, pressupõem a aceitação plena e sem reservas dos Termos e Condições de Uso destas Bibliotecas Digitais, disponíveis em https://digitalis.uc.pt/pt-pt/termos.

Conforme exposto nos referidos Termos e Condições de Uso, o descarregamento de títulos de acesso restrito requer uma licença válida de autorização devendo o utilizador aceder ao(s) documento(s) a partir de um endereço de IP da instituição detentora da supramencionada licença.

Ao utilizador é apenas permitido o descarregamento para uso pessoal, pelo que o emprego do(s) título(s) descarregado(s) para outro fim, designadamente comercial, carece de autorização do respetivo autor ou editor da obra.

Na medida em que todas as obras da UC Digitalis se encontram protegidas pelo Código do Direito de Autor e Direitos Conexos e demais legislação aplicável, toda a cópia, parcial ou total, deste documento, nos casos em que é legalmente admitida, deverá conter ou fazer-se acompanhar por este aviso.

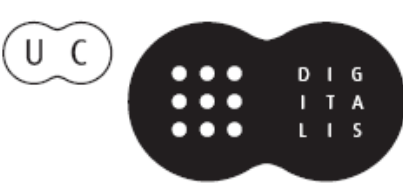



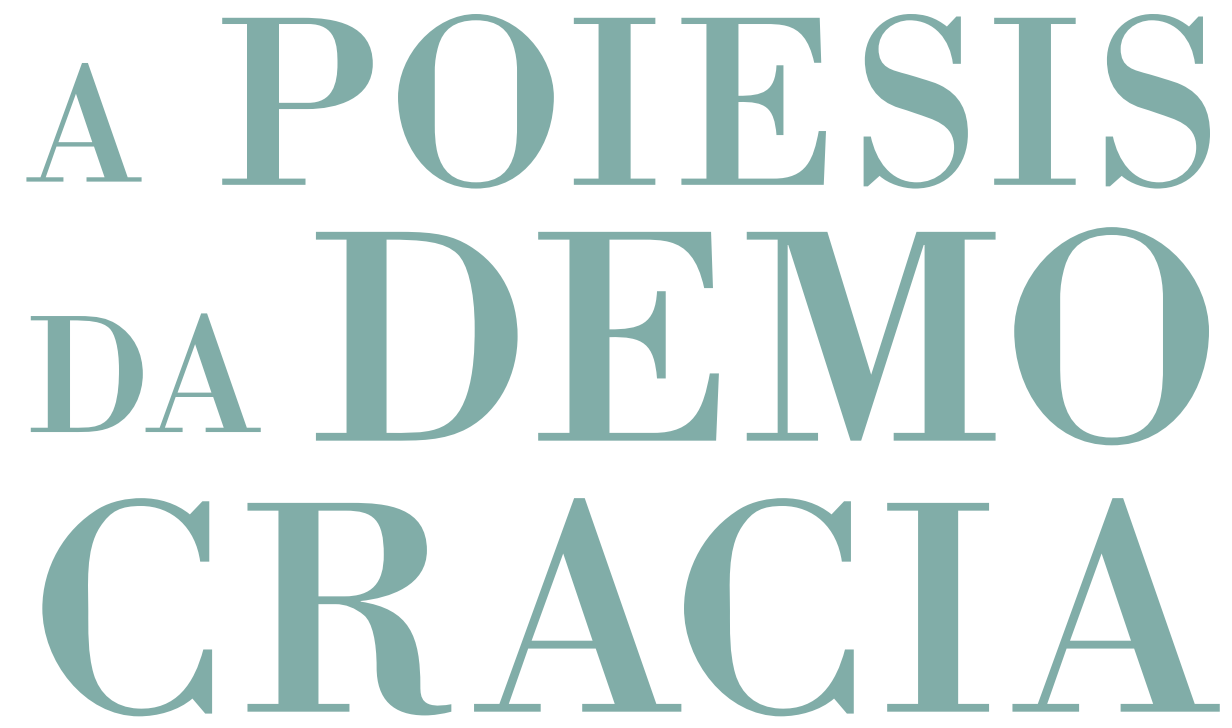

G

Breno Battistin Sebastiani, Delfim Leão,

Lugia Sano, Martinho Soares, Christian Werner

\section{CoimbraCompanions}




\section{Iconografia e ideologia política:}

A REPRESENTAÇÃO DA MISSÃO DE TRIPTÓlEMO E DE CENAS DE FAMÍliA NA PINTURA DE VASOS Áticos

\section{ICONOGRAPHY AND POLITICAL IDEOLOGY :}

THE REPRESENTATION OF THE MISSION OF TRIPTOLEMOS AND OF FAMILY SCENES IN ATTIC VASE PAINTING

Luísa de Nazaré Ferreira

Universidade DE COIMBra

ORCID | 0000-0001-9958-5448 


\section{Resumo*}

Este estudo centra-se na análise da iconografia de dois conjuntos de vasos áticos - o primeiro baseado na tradição mitológica (a missão de Triptólemo) e o segundo no quotidiano ateniense (cenas de família) -, com vista a examinar a hipótese, sugerida em estudos anteriores, de existir uma relação entre a prevalência destes temas na cultura visual de Atenas e a ideologia subjacente à política democrática, em particular no que respeita às reivindicações imperialistas atenienses e à proposta de Péricles de redefinir o estatuto de cidadão.

\section{Palavras-chave}

pintura de vasos áticos, mito e política, ideologia democrática, identidade cívica 


\section{Abstract}

This study focuses on the iconographical analysis of two sets of Attic vases the first one based on the mythological tradition (the mission of Triptolemos), and the second one inspired by Athenian daily life (family scenes) -, in order to examine the hypothesis, already noted in earlier studies, of an existing relationship between the prevalence of these themes in Athenian visual culture and the underlying ideology of democracy, in particular with regard to Athenian imperialist claims, and to Pericles' proposal to redefine citizen status.

\section{Keywords}

Attic vase painting, myth and politics, democratic ideology, civic identity 
O estudo que propomos, que se centra no período compreendido entre meados do século VI e o final do século V a.C., baseia-se no pressuposto de que é possível detetar neste período da história de Atenas relações de natureza vária entre a iconografia da pintura de vasos áticos e a ideologia política vigente, no sentido em que entendemos que essas imagens, inspiradas na tradição mitológica e nas atividades do quotidiano ateniense, foram também utilizadas com vista a reforçar ou impor ideias que tinham um alcance político, económico ou social significativo, e a sua existência não se limitava, portanto, a uma função meramente decorativa.

A ligação entre a difusão de determinados temas e motivos artísticos na arte ateniense e o contexto histórico e político de produção das obras, sustentando, por exemplo, a construção de uma identidade ateniense (e.g. Teseu e o Minotauro; o nascimento de Erictónio e o mito da autoctonia; figurações do Outro, como o Cita, o Persa e a Amazona; os Tiranicidas1), é uma problemática que tem suscitado o interesse de um grande número de investigadores e essa atenção explica-se também pelo facto de a maior parte dos monumentos artísticos que subsistiram, como os edifícios erguidos na Acrópole de Atenas por iniciativa de Péricles, ter sido uma criação oficial da polis e do regime democrático ${ }^{2}$. No entanto, o exame desta matéria não está isento de dificuldades, pois o material que nos propomos estudar - o corpus de vasos áticos preservados - constitui apenas uma pequena parte

1 A representação comemorativa de Harmódio e Aristogíton, responsáveis pela morte de Hiparco, tem a particularidade de remeter para um acontecimento histórico cujas circunstâncias não são fáceis de elucidar, como bem demonstra neste volume N. S. Rodrigues. Parece, porém, evidente que a escultura e a pintura de vasos, além das canções de mesa, é que permitiram que a memória de um ato de vingança pessoal se consolidasse num ideal de heró́smo em benefício da polis.

2 Vide e.g. Boardman 1972, 1975b, 1984, 1989b; Shapiro 1989: 15-17; Castriota 1992; Boedeker and Raaflaub 1998; Neer 2002; e o capítulo de N. S. Rodrigues neste volume. 
do que foi efetivamente produzido e, na maioria dos casos, desconhecemos o contexto de fabrico e, sobretudo, de descoberta das peças. Por outro lado, além de estarmos perante um medium artístico que apela ao olhar do observador através de um conjunto de convenções e signos codificados (e.g. prevalência de figuras de perfil, atributos e adereços identitários, gestos convencionais, elementos identificativos de espaço interior/exterior, esquemas iconográficos), que não podem ser interpretados literalmente ${ }^{3}$, não é fácil examinar os contornos de uma relação que se pauta pela alusão e pelo subentendido, à semelhança do modo como opera a publicidade na sociedade contemporânea ocidental (capitalista e democrática) que, através da imagem visual, comunica ao consumidor ideias, promessas e desejos, estimulando a sua imaginação, mas raramente de forma explícita ${ }^{4}$.

\section{A representaÇão da missão de Triptólemo na pintura de vasos} ÁtICOS

Um fenómeno corrente em regimes políticos de essência autoritária é a veneração obsessiva das letras e das artes, que funciona em geral sob a forma de proteção, controlo ou perseguiçãos. Essa atitude dúbia parece ter caracterizado a atuação de Pisístrato e seus filhos, pois além da promoção da poesia (em especial da homérica ${ }^{\circ}$ e da proteção de poetas, como Anacreonte, Laso de Hermíone e Simónides, são bem conhecidas outras ações de natureza cultural, religiosa e económica impulsionadas durante a tirania ateniense, uma matéria que tem sido muito discutida, designadamente pelos nossos colegas José Ribeiro Ferreira e Delfim Leãoำ. Neste trabalho

3 Cf. Beard 1991; Powell 2001: 384-392.

4 Sobre este assunto é sempre útil a releitura do capítulo que encerra o clássico Ways of Seeing (1972), de John Berger.

5 Vide e.g. o ensaio do escritor e helenista Ismail Kadaré, La légende des légendes, Paris, 1995, 29-33, no qual reflete sobre este fenómeno na sociedade moderna através do exemplo do ditador chinês Mao Zedong.

6 Sobre este ponto, vide Shapiro 1995.

7 Para uma análise global da atuação de Pisístrato e dos Pisistrátidas, vide e.g. Andrewes 1956: 100-115; Shapiro 1989: 1-17; Ferreira 2004: 65-68; Ferreira \& Leão 2010: 83-118. Sobre a política cultural dos tiranos, vide o nosso estudo publicado em Ferreira 2013: 65-96. 
importa destacar o desenvolvimento extraordinário da atividade cerâmica na região da Ática, atestado pela arqueologia e pela cultura material, em particular desde o início do século VI a.C., quando se introduz c. 570 a.C. a técnica de figuras negras, de invenção coríntia, atividade que se torna ainda mais importante durante o período da tirania. É nesta altura que, por volta de 530 a.C., os artistas áticos criam a técnica de figuras vermelhas, que vai permitir um progresso singular nos modos de representação pictórica e fomentar, no exterior, a fama dos vasos áticos, contribuindo substancialmente para a sua exportação. Escusado será lembrar que o desenvolvimento da cerâmica decorreu também da necessidade de criar recipientes que permitissem transportar os produtos exportados, como o azeite ${ }^{8}$.

Sabe-se também que uma das formas de centralização do poder por parte de Pisístrato passou pelo controlo dos espaços sagrados e pela reorganização de alguns cultos importantes, conferindo-lhes um carácter nacional: além dos festivais dionisíacos e da reforma das Panateneias, salienta-se o engrandecimento dos Mistérios de Elêusis ${ }^{9}$. Com esta promoção de um culto celebrado em honra de Deméter e Perséfone se relacionam eventualmente outras ações, de carácter económico e comercial, que tinham em vista garantir o fornecimento de cereal a Atenas, como a fundação de colónias no Helesponto para controlar a rota do trigo até ao Mar $\mathrm{Negro}^{10}$.

A circulação de imagens alusivas ao ritual de Elêusis e aos dons de Deméter, em particular através da pintura de vasos produzidos na Ática, constitui um dos exemplos mais interessantes de utilização do mito e da arte com fins propagandísticos. Pareceu-nos, por isso, que valeria a plena examinar de novo a forma como um tema iconográfico pôde funcionar com eficácia ao serviço das ambições dos Pisistrátidas e ser depois também aproveitado e explorado em plena democracia. Registe-se que a "missão de

8 Cf. Andrewes 1982: 408; Shapiro 1989: 10-12. Andrewes 1956: 112 observa, com pertinência, que não é possível determinar com exatidão o papel que tiveram os Pisistrátidas na promoção da cerâmica e de outras atividades. Sobre o desenvolvimento das oficinas de cerâmica na Época Arcaica, cf. Laurens 1995.

9 Andrewes 1956: 113-114; Forrest 1966: 184-189; Parke 1977: 34, 125-126, 128-129; Ferreira \& Leão 2010: 108-110. Sobre a reorganização dos Mistérios de Elêusis no tempo dos Pisístrato, vide esp. Mylonas 1961: 77-105; Shapiro 1989: 67-83.

10 Ferreira \& Leão 2010: 107. 
Triptólemo", desde a segunda metade do século XX, prendeu a atenção dos estudiosos que, de um modo geral, reconhecem uma ligação entre a difusão deste tema e a evolução do contexto político ateniense entre meados do século VI e o final do século V a.C. ${ }^{11}$.

Na Época Arcaica, o mito de Triptólemo difundiu-se provavelmente graças ao Hino Homérico a Deméter, que transmitiu a narrativa que sustenta a instituição dos Mistérios de Elêusis e cuja data de composição foi situada entre a segunda metade do século VII e a primeira do século VI a.C. ${ }^{12}$. Neste poema Triptólemo é um dos reis de Elêusis (vv. 149-155), a quem a deusa ensina os "atos do ritual sagrado", "os sacros mistérios, que não se podem transgredir/ nem divulgar" (vv. 473-479), como traduz M. H. Rocha Pereira (2009: 117). É, portanto, uma figura central da instituição do culto eleusino, intermediário entre Deméter e os devotos da deusa, e o seu protagonismo decorre simplesmente do facto de ser mencionado em primeiro lugar, antes de Díocles, Políxeno, Eumolpo, Dólico e Céleo (cf. vv. 153-155, cf. v. 477). No entanto, neste hino não há qualquer referência à missão que Deméter lhe confia de transmitir a cultura do cereal aos outros povos da Hélade. Em versões mais tardias, Triptólemo é um príncipe de Elêusis, filho de Céleo e Metanira. De acordo com um passo da Biblioteca atribuída a Apolodoro (1.5.2), Deméter "preparou para Triptólemo, o mais velho dos filhos de Metanira, um carro com serpentes aladas e deu-lhe trigo que ele,

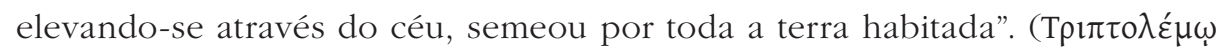

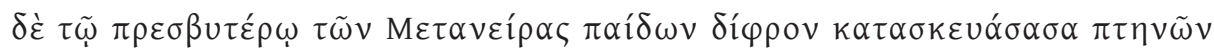

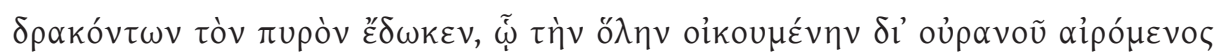

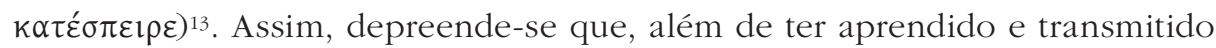

11 Cf. Mylonas 1961: 20-21; Richardson 1974: 195-196 (o A. destaca o papel de Triptólemo como Athenian 'propaganda hero'); Raubitschek \& Raubitschek 1982: 109; Foley 1994: 100; Matheson 1994: 363-372; Evans 2010: 126-127.

12 Janko 1982: 183 defende que a composição ocorreu c. 640 a.C., enquanto West 2003: 8-9 se inclina para a primeira metade do século VI a.C., observando ainda que a narrativa mítica não alude a Atenas, pelo que deve ser anterior ao tempo de Pisístrato.

13 A seguir a estas linhas observa-se que a filiação de Triptólemo era muito variada: segundo Paníasis, era filho do herói Elêusis, enquanto Ferecides afirmava que era filho de Oceano e de Geia (cf. outras versões em Pausânias, 1.14.2-3). Para outras versões da história de Triptólemo, cf. Higino, Fab. 147, 259, 277; Astr. 2.14. Vide Pearson 1917: 239-242; Richardson 1974: 195-196; Matheson 1994: 349-350. 
os atos do ritual eleusino, Triptólemo é também aquele que, tendo recebido da deusa as sementes, assume prontamente a sua missão, tornando-se num herói civilizador da Humanidade.

Na Época Clássica uma tragédia perdida de Sófocles (497/6-406/5 a.C.) intitulada Triptólemo ${ }^{14}$, apresentada em 468 a.C. e bem acolhida, deve ter contribuído para renovar o interesse por esta figura mitológica ${ }^{15}$. Um dos fragmentos faz referência a um veículo divino com serpentes enroscadas ao eixo das rodas ${ }^{16}$, confirmando que se tratava de um elemento fundamental do mito, como as pinturas de vasos também testemunham. No entanto, a ideia de que Triptólemo havia sido escolhido por Deméter para disseminar a semente do trigo pela terra inteira pode remontar à Época Arcaica e ao tempo dos Pisistrátidas ${ }^{17}$, tendo em conta que o mito começa por ser tratado nos vasos áticos de figuras negras e que os tiranos tomaram medidas no sentido de controlar a produção cerealífera.

Num importante artigo sobre a "missão de Triptólemo", publicado em 1982, Isabelle e Antony Raubitschek começam precisamente por observar que este tema "era um tópico favorito em Atenas mesmo antes do tempo de Címon e de Péricles"18, contestando outras posições que parecem ignorar a sua antiguidade. De facto, a base digital do Arquivo Beazley (Beazley Archive Pottery Database - BAPD) regista 179 resultados para o nome "Triptolemos", sendo que 39 peças se integram na técnica de figuras negras e 140 na de figuras vermelhas, num universo de 78 artistas identificados. É importante salientar que se preservou um número significativo de vasos atribuídos a uma mesma oficina, um índice claro de popularidade. Assim, são atribuídos 12 vasos ao Pintor dos Nióbidas (fl. c. 475-450 a.C.), 11 ao Pintor de Berlim (fl. 500-460 a.C.), 9 ao Pintor de Altamura (c. 475-425 a.C.),

14 Frs. 596-617 Radt. Vide Pearson 1917: 239-253; Lloyd-Jones 1996: 300-305.

15 Cf. Pearson 1917: 239; Richardson 1974: 195; Lloyd-Jones 1996: 300. A datação da tragédia baseia-se numa informação dada por Plínio, o Antigo (Nat. 18.65).

16 Fr. 596 Radt. Vide o comentário de Pearson 1917: 243-244. Cf. Dugas 1950: 12; Matheson 1994: 367. A missão confiada por Deméter a Triptólemo depreende-se do fr. 598 Radt. Estes e outros versos contêm referências geográficas, o que sustenta a hipótese de a tragédia incluir um catálogo das regiões que haviam recebido a dádiva do cereal. Cf. frs. 600, 602, 604 Radt

17 Cf. Beschi 1988: I, 890.

18 Raubitschek \& Raubitschek 1982: 109. 
8 ao Grupo de Polignoto e 6 ao próprio Polignoto (c. 450-420 a.C.). Existe também um "Pintor de Triptólemo" (fl. c. 490-470 a.C.), ao qual são atribuídos três vasos sobre este tema. Se efetuarmos uma pesquisa que permita destacar a cronologia de produção das peças, a base do Arquivo Beazley devolve-nos os seguintes resultados para um total de 175 vasos de figuras negras (f.n.) e de figuras vermelhas (f.v.):

\begin{tabular}{|l|l|}
\hline 575-525 a.C. & 1 f.n. \\
\hline 550-500 a.C. & 9 f.n. \\
\hline 525-475 a.C. & 10 f.n. +14 f.v. $=24$ \\
\hline 500-450 a.C. & 3 f.n. +29 f.v. $=32$ \\
\hline 475-425 a.C. & 62 f.v. \\
\hline 450-400 a.C. & 11 f.v. \\
\hline 425-375 a.C. & 4 f.v. \\
\hline 400-300 a.C. & 14 f.n. +18 f.v. $=32$ \\
\hline
\end{tabular}

Ainda que não seja uma ferramenta absolutamente válida, porque o arquivo digital não regista todos os vasos existentes sobre o tema em análise e a informação cronológica não é consensual19, este quadro sustenta que o mito de Triptólemo se difunde na pintura de vasos desde meados do século VI a.C. e alcança grande popularidade durante a Época Clássica, quer na primeira metade do século $\mathrm{V}$ quer na segunda, registando um decréscimo ao longo do século IV, ainda que haja indícios de que continuou a ser popular, mesmo nas Épocas Helenística e Romana ${ }^{20}$.

Isabelle e Antony Raubitschek defendem que a iconografia dos vasos áticos mais antigos "é um reflexo da política de Pisístrato e dos seus filhos, que favoreceram a cultura do grão e do vinho e promoveram os cultos de Dioniso e de Deméter" ${ }^{21}$. Este estudo minucioso também mostra que a

19 A validade da consulta da BAPD para fins estatísticos não pode ser entendida de forma absoluta, uma vez que se trata de uma base digital em permanente construção e, dada a complexidade da sua manutenção, sujeita a incorreções e omissões. Apesar dessas possíveis falhas, foi uma ferramenta fundamental para a realização deste trabalho, pelo que deixamos expresso o nosso agradecimento a Thomas Mannack, seu atual Diretor.

20 Cf. os dados estatísticos discutidos por Matheson 1994: 362-363 (fig. 1), que segue uma metodologia diversa, apoiada na recolha efetuada por Hayashi 1992: 126-174.

21 Raubitschek \& Raubitschek 1982: 110. 
representação da missão de Triptólemo na pintura de vasos áticos continuou a ter um significado político e propagandístico, mantendo uma relação direta com os interesses dos democratas e com a evolução da história política, militar, económica e religiosa de Atenas. Entre os muitos factos que os historiadores assinalam destacamos três: a crença de que Deméter havia ajudado os Atenienses na batalha de Salamina (cf. Heródoto, 8.65; Plutarco, Them. 15), matéria que Nuno Simões Rodrigues discutiu num estudo em vias de publicação ${ }^{22}$; a preocupação com o culto e santuário de Elêusis, que levou a intervenções no espaço sagrado no tempo de Péricles (confirmadas pela arqueologia)23; e a promulgação do "Decreto das Primícias"24, possivelmente c. 422 a.C., que impôs que todas as cidades aliadas de Atenas realizassem sacrifícios no santuário de Elêusis e prestassem um tributo anual em honra de Deméter e Perséfone, sob a forma de oferendas de cevada e trigo, estando nesta medida subjacente a ideia de que esta taxa não era mais do que uma retribuição pela ação civilizadora que, através do mítico Triptólemo, Atenas havia prestado às outras cidades gregas ${ }^{25}$.

Um exame breve de uma seleção de oito vasos permite identificar os elementos iconográficos básicos da representação do mito de Triptólemo, sendo evidente que a maior evolução diz respeito à sua fisionomia, pois é retratado como um homem maduro ou ancião nas figuras negras (com barba) e como jovem imberbe nas figuras vermelhas. Este rejuvenescimento pode ser um reflexo da própria transição política, mas talvez seja mais legítimo relacioná-lo com as fontes literárias que difundiram o mito. Recorde-se que

22 "A Goddess for the Greeks. Demeter as Identity Factor in Herodotus". Agradecemos ao nosso colega o acesso a este trabalho antes da sua publicação.

23 Vide e.g. Mylonas 1961: 106-129; Evans 2010: 119-120.

24 First Fruits Decree, Aparchai: IG $1^{3}$. 78a (cf. IG $\left.1^{2} .76\right)=I$ Eleus. $28 \mathrm{a}(P H I)=$ ML 73. A datação é muito incerta. Seguimos Meiggs \& Lewis 1988: 217-223, que publicam e comentam a inscrição, recuperada a partir da estela em mármore descoberta em Elêusis e de um pequeno fragmento da sua cópia encontrado na Acrópole de Atenas (p. 217), e discutem a questão cronológica (pp. 222-223); http://epigraphy.packhum.org/text/79 (The Packard Humanities Institute - PHI Greek Inscriptions); https://www.atticinscriptions.com/inscription/ IEleus/28a (Attic Inscriptions Online).

25 Richardson 1974: 196; Raubitschek \& Raubitschek 1982: 112, 117; Boedeker 2007: 75; Evans 2010: 127-128 (cf. p. 100); Rodrigues, art. cit. (n. 22). 
no Hino a Deméter Triptólemo é um dos reis de Elêusis, enquanto nas fontes posteriores é o príncipe de Elêusis e, supostamente, uma figura mais jovem ${ }^{26}$.

A iconografia canónica coloca Triptólemo junto ou sobre um carro que nos primórdios é apenas constituído pelo assento e pelas rodas (como um trono móvel). Nas mãos segura os atributos da sua missão: as espigas na mão esquerda e um cetro na direita, como na ânfora de Providence ${ }^{27}$, um dos vasos mais antigos da coleção (registe-se que o lado B deste vaso é decorado com a luta entre Teseu e Minotauro, outra tema favorito do imaginário ateniense). Em redor de Triptólemo surgem normalmente as deusas do culto eleusino, pelo que se supõe que as figuras femininas presentes neste vaso sejam Perséfone e Deméter. Noutras pinturas, em vez das deusas temos figuras masculinas e femininas, que representam os povos que receberam as dádivas de Triptólemo, como exemplificam duas ânforas de figuras negras conservadas em Göttingen ${ }^{28}$ e Bruxelas ${ }^{29}$.

Outra evolução no tratamento iconográfico deste tema é a sofisticação do carro divino que passa a ser alado, motivo que ainda é introduzido nas figuras negras, como dá testemunho um lécito pertencente à Universidade de Nuremberga ${ }^{30}$, e se torna depois muito comum. Além de Triptólemo

26 Sobre o rejuvenescimento de Triptólemo na iconografia ática, cf. Dugas 1950: 9-11. Richardson 1974: 195 observa que essa evolução física também ocorre na arte grega com Teseu e outros heróis, explicação que Simon 1997: 99 privilegia. No caso de Triptólemo, este desenvolvimento culmina no grande relevo votivo descoberto em Elêusis (c. 440-430 a.C.), hoje no Museu Nacional de Atenas (inv. 126), no qual surge representado como adolescente. Vide Mylonas 1961: 192-193, fig. 68; Boardman 1991: 182, fig. 144; http://www. namuseum.gr/collections/sculpture/classical/classic06-en.html.

27 Ânfora ática de figuras negras, c. 550-530 a.C. (Providence, Rhode Island School of Design 25.083); LIMC Triptolemos 57; http://www.beazley.ox.ac.uk/record/0218E445-29DB4A90-9F95-ACBA79440561 (BAPD 4808).

28 Ânfora ática de figuras negras atribuída ao Pintor do Baloiço (Swing Painter), c. 550500 a.C. (Georg-August-Universität Göttingen J 14); LIMC Triptolemos 54; Simon 1997: 99, fig. 2; http://www.beazley.ox.ac.uk/record/332F2335-11C5-41CE-9AD4-E97517691042 (BAPD 301562).

29 Ânfora ática de figuras negras atribuída ao Pintor do Baloiço, c. 550-500 a.C. (Bruxelas, Musées Royaux A130); LIMC Triptolemos 53; Boardman 1974: 219, fig. 146; http://www. beazley.ox.ac.uk/record/E7436F24-8A84-40AB-B2B4-12A77FD75C0F (BAPD 301561).

30 Lécito ático de figuras negras atribuído ao Pintor de Teseu, c. 525-475 a.C. (ErlangenNürnberg, Friedrich-Alexander-Universität I238); LIMC Demeter 335; http://www.beazley.ox.ac. uk/record/DAEE0438-0B96-4DDE-A0AD-48B9BF3A91CA (BAPD 390478). 
parecer mais jovem neste lécito, recebe uma phiale (vaso para a realização do ritual da libação), outro elemento característico destas pinturas ${ }^{31}$.

Menos vulgar é a presença do príncipe junto do carro, como ocorre num krater preservado em Karlsruhe ${ }^{32}$. À esquerda, uma figura feminina com um polos (coroa) sobre a cabeça e espigas em ambas as mãos é de imediato identificada com Deméter. O altar assinala o sentido divino da missão confiada a Triptólemo que segura o seu cetro, junto de um carro alado. A certa altura, provavelmente, o tema iconográfico tornou-se tão conhecido que o veículo divino e as espigas seriam suficientes para identificar a missão de Triptólemo, como se depreende de uma singular hídria que se encontra em Nova Iorque ${ }^{33}$. Nesta pintura as espigas saem das mãos do herói como se fossem rédeas e a impressão geral é a de que o carro alado está a pairar, pelo que se depreende que o artista pretendia representar a viagem de Triptólemo a atravessar o céu (cf. supra o passo citado do Pseudo-Apolodoro).

Uma outra novidade pode ser ilustrada por um skyphos com inscrições atribuído ao pintor Mácron ${ }^{34}$ onde vemos, no lado A, Triptólemo sobre um carro alado e agora também com serpentes, motivo que é também evocado na tragédia de Sófocles (fr. 596 Radt, cf. supra), em princípio levada à cena em data posterior a este vaso. Atrás do príncipe encontra-se Deméter com espigas e tochas. À frente do carro, Perséfone (Perephatta) faz uma libação; atrás dela uma outra figura feminina surge identificada como sendo Elêusis, personificação do santuário eleusino e, nalgumas versões, mãe de Triptólemo (cf. Pausânias, 1.14.2). Embora as composições que se preservam sejam

31 Cf. Simon 1997: 99-101.

32 Krater de volutas ático de figuras negras atribuído ao Pintor de Berlim, c. 525-475 a.C. (Karlsruhe, Badisches Landesmuseum 68.101); LIMC Demeter 340; Boardman 1975a: fig. 154; http://www.beazley.ox.ac.uk/record/675A603B-0222-40E8-8478-0690AF97F988 (BAPD 352484).

33 Hídria ática de figuras vermelhas atribuída ao Pintor de Troilo, c. 490 a.C. (Nova Iorque, The Metropolitan Museum of Art 56.171.53); LIMC Triptolemos 85; Boardman 1975a: 113, fig. 189; http://www.metmuseum.org/art/collection/search/254912.

34 Skyphos ático de figuras vermelhas atribuído a Mácron, c. 500-480 a.C. (Londres, The British Museum E140); LIMC Demeter 344; Boardman 1975a: 140, fig. 309; Parke 1977: fig. 30; Carpenter 1991: 36, fig. 41; http://www.beazley.ox.ac.uk/record/4273528F-256B-48D0A436-94D7F24CBD36 (BAPD 204683). 
todas diferentes, o programa iconográfico da missão de Triptólemo vai evoluir pouco dentro das figuras vermelhas, mas mantém-se coerente ${ }^{35}$.

Os estudiosos recordam que há ecos importantes desta tradição nos autores atenienses da transição do século V para o IV a.C., nomeadamente em Isócrates (Panegírico 28-29, 31, 38), Xenofonte (Helénicas 6.3.6) e Platão (Menéxeno 237e-238b) ${ }^{36}$, mas parece certo que, no que respeita à representação iconográfica da missão de Triptólemo, embora não tenha sido abandonada, perdeu a pouco e pouco o significado político que a acompanhara provavelmente desde o tempo dos Pisistrátidas. Dado que algumas peças foram encontradas na Itália, como o vaso atribuído a Mácron, proveniente de Cápua, sabemos que estas imagens também circularam fora de Atenas. Quanto ao suporte cerâmico, este mito surge tratado com mais frequência em ânforas, choes, taças, krateres, lécitos e skyphoi, ou seja, em vasos usados no serviço de banquete, bem como em ânforas panatenaicas. É fácil concluir que, à exceção das peças destinadas a mercados exteriores, o recetor principal destes vasos era o cidadão ateniense.

\section{A lei da Cidadania E as imagens de família nos vasos áticos de FIGURAS VERMELHAS}

Em 451/450 a.C. Péricles promulgou uma lei que restringiu a atribuição do estatuto de cidadão aos indivíduos filhos de pai e mãe atenienses, quando até então bastava a naturalidade do pai. Trata-se de uma medida legislativa que, juntamente com a instituição da mistoforia, pela qual se remunerava a prestação de serviços públicos, é considerada basilar do regime democrático. Os motivos e objetivos da chamada lei da cidadania, bem como outras questões suscitadas pelo tratado aristotélico que a transmitiu, a Constituição dos Atenienses (26.4, 42.1, cf. Aristóteles, Pol. 3.1275b, 3.1278a; Plutarco,

35 Cf. e.g. krater ático de figuras vermelhas, c. 470-460 a.C. (Paris, Louvre G368); LIMC Demeter 348; http://www.beazley.ox.ac.uk/record/9ECCD9C5-C509-4122-BE14-E9BCD7645C0C (BAPD 205638). Para uma análise mais detalhada da evolução do tema de Triptólemo nas pinturas de vasos, vide Dugas 1950; Raubitschek \& Raubitschek 1982; Shapiro 1989: 76-77; Matheson 1994: 350-362; Simon 1997.

36 Cf. Raubitschek \& Raubitschek 1982: 117; Matheson 1994: 368-370. 
Per. 37.2-5), e outras fontes que se relacionam com esta matéria, como o discurso Contra Neera atribuído a Apolodoro (cf. 16-17), têm sido objeto de uma discussão aprofundada, para a qual contribuíram também as reflexões importantes de José Ribeiro Ferreira e Delfim Leão. A razão apontada pelo tratado aristotélico de que a medida tinha em vista reduzir o número elevado de cidadãos (Ath. 26.4) talvez explique a sua suspensão no decurso da Guerra do Peloponeso, para ser restabelecida em 403/402 a.C. (a peste que assolou Atenas e as baixas causadas pelo conflito poderão ter contribuído para o mesmo fim) ${ }^{37}$, mas a questão revela-se muito mais complexa e difícil de alcançar conclusões definitivas e consensuais ${ }^{38}$.

Não é nossa intenção discutir os motivos nem os aspetos de ordem jurídica, mas antes refletir um pouco sobre o impacto social e cultural que esta medida possa ter tido. De facto, até então nada impedia que as famílias mais influentes de Atenas estabelecessem, através do matrimónio dos seus descendentes varões, alianças com famílias de outras póleis. Não é de estranhar, por isso, que figuras relevantes da vida política da primeira metade do século V a.C. tivessem mãe não ateniense. É plausível que a lei da cidadania tenha contribuído para um processo de endogamia, reduzindo igualmente a rede de relações das famílias de Atenas ${ }^{39}$. É também legítimo supor que uma norma desta natureza tenha chamado a atenção para a mulher ateniense, promovendo o seu estatuto social e legal, uma ideia que tem acolhido consenso entre os estudiosos. Ana Iriarte observa, com pertinência, que este novo status, no que respeita à relevância que o discurso político atribuía à função reprodutora da mulher, era uma espada de dois gumes: "Por una parte, al reconocer a la mujer como generadora de una identidad cívica - que sólo los varones detentarán, eso sí, de forma íntegra - se la reconoce como un elemento imprescindible para definir la empresa

37 Pomeroy 1995: 66-67; Blok 2009: 168: Ferreira \& Leão 2010: 200 e n. 391. Patterson 1981: 40-81 examina em detalhe a questão demográfica, com revisão da bibliografia anterior. Sobre o restabelecimento da lei, vide pp. 140-150.

38 Vide e.g. Patterson 1981: 1-3, 95-139; Just 1989: 60-62; Stadter 1989: 333-338; Rhodes 1993: 331-335; Boegehold 1994; Osborne 1997: 4-11; Blok 2009; Ferreira \& Leão 2010: 199203; Leão 2011: 13-18.

39 Cf. Lacey 1968: 100-103; Patterson 1981: 99-100, 130; Leduc 1993: 340; Boegehold 1994: 58; Osborne 1997: 6-9. Sobre os casamentos mistos e o impacto da lei de Péricles, cf. Blok 2009: 149-150, 156-157, 169. 
política. Por otra, este reconocimiento implicará un mayor control de la esposa legítima; control recompensado por un puesto de honor en la casa y por la protección legal de los hijos legítimos frente a los bastardos que el esposo pudiera tener de concubinas o esclavas." ${ }^{\circ}$. A consciência da importância da mulher, não apenas como mãe e esposa, mas também como filha, que parece estar subjacente nalguns diálogos do teatro ático, trágico e cómico, em particular nas reflexões sobre a condição feminina que surgem expressas através de personagens como Medeia, Antígona, Andrómaca e Lisístrata, pode ser um reflexo de uma mudança na mentalidade social em plena democracia ateniense ${ }^{41}$.

O nosso contributo para esta discussão baseia-se no exame de um pequeno corpus de vasos áticos de figuras vermelhas e na constatação de que no terceiro quartel do século V a.C., ou seja, nos 25 anos que se seguiram à proposta de Péricles, parece haver um interesse maior na representação do oikos, do núcleo familiar que, de acordo com Aristóteles (Pol. 1.1253b), englobava, além do kyrios, a esposa, os filhos e os escravos (cf. MacDowell 1989). A existência de uma relação entre os efeitos sociais da lei da cidadania, promulgada em plena democracia, e a prevalência, na pintura de vasos áticos, de uma iconografia que expõe o interior doméstico tem sido reconhecida em particular nos estudos centrados na infância e na família atenienses, mas não sem reservas ${ }^{42}$. Nesta perspetiva de análise está subjacente o entendimento, como foi dito no início deste estudo, de que estas pinturas inspiradas na realidade do quotidiano não tinham apenas

40 Iriarte 2002: 133. Cf. Gould 1980: 45-46; Just 1989: 62; Osborne 1997: 4; Blok 2009: 159, 166; Evans 2010: 108 ("This law gave Athenian women a new status in the polis, and presented male citizens with new incentives for marrying well. The stability of Athenian society rested on the security of the family and the trustworthiness of its female citizens unmarried maiden daughters as well as lawful, childbearing wives."); Iriarte 2015: 14-15. Relativamente à situação real da mulher ateniense, a nossa posição coincide com a de Cohen 1989.

41 Cf. Osborne 1997: 31-32; Powell 2001: 390. Sobre a relação entre democracia e teatro ático vide, neste volume, os estudos de Ch. Werner e de M. F. Silva.

42 Cf. Beaumont 2003: 72; Sutton 2004: 347; Golden 2015: 149-150. Osborne 1997: 11-33 discute o impacto social da lei de Péricles a partir da análise da representação da mulher na escultura funerária ateniense, muito mais frequente desde a segunda metade do século V a.C. O estudo dedica também atenção, pelo mesmo facto, aos lécitos áticos de fundo branco (pp. 16-18). Barringer 2008: 95-96 adota uma perspetiva similar no estudo das esculturas do Pártenon. 
uma função decorativa ou didática, mas eram também expressões de uma ideologia vigente que, como sublinha François Lissarrague, corresponde a uma visão marcadamente masculina ${ }^{43}$, típica de uma sociedade mediterrânea e patriarcal. É principalmente essa "visão", que foi moldada seguramente pela cultura democrática da polis ateniense, que gostaríamos de expor nesta análise iconográfica.

Num importante artigo publicado em 2004, Robert Sutton observa que, de um modo geral, os estudiosos têm identificado o oikos em representações que exibam alguns dos seguintes aspectos: (a) um cenário doméstico, definido por elementos arquitetónicos, pela mobília ou por outros objetos da casa; (b) as mulheres desempenham tarefas domésticas, em especial relacionadas com têxteis; (c) presença de uma ou mais crianças. Sutton defende que este último critério, que remete para a função principal do casamento ateniense, a procriação, é o mais seguro para o reconhecimento do oikos nas pinturas de vasos áticos ${ }^{44}$. Embora não concordemos em absoluto com esta afirmação ${ }^{45}$, reconhecemos que a representação de uma criança pequena junto de uma mulher, acompanhadas por um homem e, por vezes, por uma outra figura feminina, que se encontram num espaço em que se distinguem um ou mais signos domésticos, constitui uma imagem plausível da família ateniense.

A consulta da base digital do Arquivo Beazley devolve 49 resultados para a pesquisa "children" e 462 para "child". Uma boa parte deste corpus corresponde aos chamados vasos choes, que eram distribuídos às crianças durante o festival das Antestérias, realizado em honra de Dioniso, e foram produzidos em grande quantidade no último quartel do século V a.C. ${ }^{46}$. As representações que nos interessam constituem um grupo muito menor, mas mesmo assim relevante, do qual apenas comentaremos alguns exemplos. Registe-se que os especialistas têm insistido na raridade das cenas de

43 Lissarrague 1993: 205-206. Cf. e.g. Keuls 1993: 3 ("Like a piece of writing, a painting can take such forms as fantasy, caricature, slander, or official propaganda."); Lessa 2010: 17, $25,66$.

44 Sutton 2004: 331.

45 Esta afirmação não considera a hipótese de as crianças surgirem em representações de outros espaços femininos interiores, como o bordel.

46 Cf. Ferreira 2011: 79-80, com referências bibliográficas. 
maternidade e de família na pintura de vasos áticos, em particular de figuras vermelhas (o que contrasta com a abundância de outras imagens da vida privada $)^{47}$, ao contrário do que se verifica nas estelas funerárias da segunda metade do século V e do século IV a.C.

Uma píxide, recipiente que servia para conter cosméticos ou jóias, pertencente hoje à Universidade de Manchester ${ }^{48}$, exemplifica um problema que dificulta o estudo da iconografia destes vasos e da sua possível relação com a legislação ateniense. De facto, se alguns especialistas situam a produção da peça c. 470-460 a.C., no Arquivo Beazley indica-se um período mais largo, que vai de 475 a 425 a.C. Ou seja, por vezes, não podemos saber se o vaso é anterior ou posterior à promulgação da lei.

Embora a píxide de Manchester não esteja bem preservada, é possível identificar num dos lados, à esquerda, uma mulher sentada numa cadeira de encosto (klismos), com um bebé do sexo masculino apoiado no regaço. Apanhou o cabelo com o chamado sakkos ("saco, bolsa"), uma espécie de touca, e enverga um quíton ou vestido com mangas. À sua frente encontra-se de pé uma outra figura (cuja identidade não é segura) e entre ambas avista-se uma faixa suspensa ou cinta, peça da indumentária feminina (zone, cf. Il. 14.181, Od. 5.231, 10.544) que com frequência aparece em representações do interior familiar, tal como a coroa (no outro lado do vaso), pois aludem à união matrimonial. Um outro signo de intimidade feminina é o espelho, que surge suspenso entre as figuras femininas de um lécito datado da mesma época que se encontra em Atenas ${ }^{49}$. Nesta peça, a senhora, sentada à direita, surge caracterizada de forma semelhante, e ergue os braços na direção de uma escrava, familiar ou amiga, para receber uma criança do sexo masculino. A anatomia do corpo infantil ainda não é representada com rigor, mas o facto de a criança usar à volta do peito um colar de

47 Cf. Lissarrague 1993: 231; Massar 1995: 27; Neils \& Oakley 2003: 230, 237; Sutton 2004: 337, 347. Merece destaque o estudo de Bonfante 1997.

48 Píxide ática de figuras vermelhas, c. 470-460 a.C. (Manchester Museum, The University of Manchester 40096); Lewis 2002: 81-82, fig. 2.26; http://www.beazley.ox.ac.uk/record/ FF72F569-8458-4BC1-8C32-DA4A47CCFFB1 (BAPD 212513).

49 Lécito ático de figuras vermelhas atribuído ao Pintor de Bolonha 228, c. 470-460 a.C. (Atenas, Museu Nacional 1304); Cohen 2011: 480, fig. 38.7; http://www.beazley.ox.ac.uk/ record/2E66346E-2757-4F2F-849F-2DA02474078E (BAPD 9025010). 
amuletos (que tinha a função de a proteger) confirma que se trata de um bebé.

Preservaram-se outros vasos com uma iconografia idêntica, na qual se destaca uma criança pequena do sexo masculino a passar dos braços de uma mulher para outra, um motivo característico das imagens do nascimento de Erictónio, quando Geia o entrega a Atena ${ }^{50}$. A popularidade desta simples composição talvez resida no facto de concentrar algumas ideias fundamentais relativamente ao casamento e ao papel social da mulher grega: a importância da maternidade e da descendência masculina. Numa hídria fabricada já em data posterior à promulgação da lei de Péricles, pertencente ao Museu Britânico51, o pintor tornou mais evidente o gesto de passar a criança à mãe e acrescentou o chamado kalathos ou cesto, outro signo doméstico que alude ao trabalho com têxteis. Tornou também explícito o sexo do bebé. Esta iconografia faria igualmente parte do repertório dos lécitos funerários de fundo branco, como testemunha um vaso conhecido atribuído ao Pintor de Aquiles ${ }^{52}$, bem como um fragmento que se encontra no Museu Britânico53. Vemos ainda estas imagens nas estelas funerárias áticas da segunda metade do século V a.C. ou posteriores, normalmente para recordar mulheres que perderam a vida durante o parto ${ }^{54}$.

50 Cf. Robertson 1992: 203; Oakley 2013: 161, fig. 7.9. Dirigir um ou ambos os braços para um adulto é o gesto infantil mais comum na cerâmica ática. Vide McNiven 2007, esp. p. 87.

51 Hídria ática de figuras vermelhas atribuída ao Pintor de Munique 2528, c. 440-430 a.C. (Londres, The British Museum E219); Beard 1991: 24, fig. 5; Keuls 1993: 110, fig. 96; Fantham et alii 1994: 104, fig. 3.19; http://www.beazley.ox.ac.uk/record/8A413268-408B-4D9C9BAB-C753386759B4 (BAPD 217063).

52 Lécito ático de fundo branco atribuído ao Pintor de Aquiles, c. 450-445 a.C. (Berlim, Antikensammlung F2443); Keuls 1993: 139, fig. 123; Boardman 1989a: fig. 261; http://www. beazley.ox.ac.uk/record/BC610943-4199-4B53-8D91-1CCF944918D7 (BAPD 213940).

53 Lécito ático de fundo branco atribuído ao Pintor de Bosanquet, c. 450-440 a.C. (Londres, The British Museum 1905.7-10.10); Robertson 1992: 203, fig. 213; Keuls 1993: 139, fig. 122; Boardman 1997: 242 e n. 15; http://www.beazley.ox.ac.uk/record/E355A354-2714-4F44-B55033316EFBOFA6 (BAPD 216338).

54 E.g. estela funerária ática em mármore, c. 420-410 a.C. (Leiden, Rijksmuseum I 1903/2.1); CAT 2.652; Oakley 2000: 235-236, fig. 9.5; Foley 2003: 133, fig. 25; estela funerária ática de Phylonoe, primeiro quartel do século IV a.C. (Atenas, Museu Nacional 3790); CAT 2.780; http://www.hellenicaworld.com/Greece/Museum/NationalMuseumAthens/en/NAMAML3790. html. 
A pintura de uma hídria atribuída ao Grupo de Polignoto55, fabricada alguns anos após a proposta de Péricles, insere os elementos básicos desta iconografia num cenário doméstico mais completo, no qual está presente, à direita, uma figura masculina. No lado oposto vê-se um grande tear, referência explícita ao trabalho com têxteis e talvez também ao espaço do gineceu (gynaikeion). A senhora, sentada no centro da representação, surge caracterizada de forma convencional e a jovem que se encontra à sua frente destaca-se pela veste menos vulgar, sobreposta sobre o quíton, de mangas compridas, que na opinião de alguns estudiosos indica o seu estatuto servil56. O seu corpo inclinado sugere que se prepara para segurar no menino que para ela dirige os braços. O artista não se aplicou na reprodução rigorosa da fisionomia infantil, mas o colar de amuletos não deixa dúvidas sobre a faixa etária da criança. Uma coroa suspensa no centro da cena pode indicar uma união matrimonial recente ${ }^{57}$, mas é também um elemento assíduo nas cenas de família. A identificação das figuras deste vaso tem suscitado interpretações diversas. Já se pôs a hipótese de a mulher sentada ser uma avó, tomando-se como paralelo a célebre estela funerária de Anfarete (cf. Sutton 2004: 340), que, se não conhecêssemos a inscrição, poderíamos pensar que representa uma mãe com o seu filho ${ }^{58}$. De acordo com esta interpretação, a mãe da criança seria a mulher que está de pé. Por outro lado, tem sido questionada a identificação da figura masculina com o kyrios, preferindo alguns estudiosos considerar que se trata de um filho mais velho, uma vez que ele é imberbe e parece inclusive mais jovem do que a mulher sentada (cf. Williams 1993: 94). Sobre este aspeto, cremos que é bastante elucidativo o confronto com representações de pares de

55 Hídria ática de figuras vermelhas atribuída ao Grupo de Polignoto, c. 440-430 a.C. (Cambridge, Harvard University Art Museums, Arthur M. Sackler Museum 1960.342); Keuls 1993: 73, fig. 58; Massar 1995: 34, fig. 6; Lewis 2002: 16-17, fig. 1.3; Beaumont 2003: 72; Neils \& Oakley 2003: 221, 230 (cat. 29); Sutton 2004: 339-340, fig. 17.10; Lessa 2010: 60-63; Ferreira 2011: 78; http://www.harvardartmuseums.org/art/288891; http://www.beazley.ox. ac.uk/record/91D01E86-1D97-4A5D-99F1-8ADF89B23102 (BAPD 8184).

56 Cf. Massar 1995: 34; Neils \& Oakley 2003: 230. Sobre o chamado chiton cheirodotos, vide Lee 2015: 121-122. Cf. Oakley 2000: 237.

57 Cf. Massar 1995: 34; Neils \& Oakley 2003: 230.

58 Estela funerária ática em mármore de Anfarete e seu neto, final do século V a.C. (Atenas, Museu do Cerâmico P 695, I 221); CAT 1.660; Boardman 1991: 184, fig. 150; Neils \& Oakley 2003: 3, fig. 1; Sutton 2004: 330 e fig. 17.2; Beaumont 2012: 98, fig. 3.36. 
noivos ou composições similares. De facto, notou-se que na pintura de vasos áticos em geral o noivo é representado imberbe, enquanto a noiva aparenta ser já uma mulher madura, oferecendo estas imagens um contraste notável com o que provavelmente acontecia na realidade ateniense ${ }^{59}$. Ou seja, estas peças, destinadas às jovens nubentes, difundem uma imagem idealizada e romantizada da união matrimonial. No que respeita à hídria de Harvard, cremos que têm razão os estudiosos que, atendendo à qualidade da peça, consideram que seria um presente ideal para uma noiva (cf. Beaumont 2003: 72) e que todo o programa iconográfico vai no sentido de exaltar o papel social da mulher ateniense, insistindo, naturalmente, na ideia de que uma das suas funções era dar filhos varões à polis ateniense.

Embora apresente uma composição iconográfica diferente, uma hídria que se encontra hoje em Munique ${ }^{60}$ reúne os mesmos elementos figurativos, que ocupam posições similares. À esquerda, uma mulher, que pode ser uma ama, familiar ou amiga, ergue um objeto que é identificado com um tear de mão (Beazley Archive) e uma caixa de cosméticos (Sutton 2004: 340). Junto dela encontra-se um menino com idade suficiente para caminhar, uma figuração que contrasta com outras representações do mesmo género, mas devemos ter presente que estamos a trabalhar com um corpus de imagens bastante reduzido. O menino está coroado e tem na mão esquerda um aro, um brinquedo tradicional que exigia alguma agilidade física. Talvez por isso, R. Sutton supõe que a criança possa ter cinco ou seis anos de idade (2004: 340, 344). As linhas do seu corpo estão mais próximas das de um atleta do que de uma criança, não necessariamente porque o pintor seja inábil, mas porque a figuração dá a ver o que se espera que este novo elemento da polis venha a ser e não o que ele é enquanto criança. No centro da cena, surge a senhora do oikos retratada de forma convencional

59 E.g. loutrophoros (vaso para o banho nupcial) ático de figuras vermelhas, c. 450-425 a.C. (Boston, Museum of Fine Arts 03.802); Oakley \& Sinos 1993: 36, figs. 105-107; Sutton 2004: 329, fig. 17.1; http://www.mfa.org/collections/object/bathing-vessel-loutrophorosdepicting-a-bridal-procession-153797.

60 Hídria ática de figuras vermelhas atribuída ao Pintor de Clio, c. 475-425 a.C. (Munique, Antikensammlungen, SL476); Keuls 1993: 244-245, fig. 219; Massar 1995: 34; Beaumont 2003: 75-76, fig. 12; Sutton 2004: 340-341, fig. 17.11; Beaumont 2012: 106, fig. 4.2; http://www. beazley.ox.ac.uk/record/D6CB553F-55A3-4830-AE77-C69EDCD8D715 (BAPD 214538). 
como noutras representações idênticas: está também sentada numa cadeira de encosto, segura nas mãos o fuso e junto dela encontra-se o cesto, objetos que evocam o fabrico das fibras de lã e linho. À direita encontra-se um homem retratado de forma muito semelhante à figura masculina da hídria de Harvard. De facto, é também imberbe, tem o corpo envolto num manto e um bastão na mão direita, elementos que são signos de exterioridade e da vida pública do cidadão ateniense (Beard 1991: 23). Uma faixa suspensa

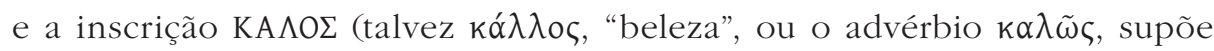
Sutton 2004: 341) no pescoço do vaso confirmam que estamos perante uma imagem idealizada do oikos, na qual se engrandecem a maternidade e o trabalho com têxteis.

Muito provavelmente os artistas criaram composições iconográficas muito mais diversas, com a mesma ideologia subjacente, mas que não se preservaram. De facto, é natural que esta iconografia também decorasse um vaso como o lebes gamikos, no qual se recolhia a água para o banho da noiva, que dava início ao ritual do casamento, como testemunha um vaso que se encontra em Atenas ${ }^{61}$. Num cenário com vários elementos que sugerem o gineceu, rodeada por outras figuras femininas, uma mulher sentada numa cadeira de encosto ergue uma criança pequena. O vaso nupcial alude talvez à vida futura da noiva e ao júbilo da maternidade ${ }^{62}$. Finalmente, a decoração de um dos lados de uma pelike fabricada possivelmente após a lei de Péricles, hoje no Museu Britânico63, tem sido interpretada como uma imagem do oikos ou, pelo menos, de um interior doméstico, como assinala o sakkos suspenso da parede. Já foi avançada a hipótese de a figura masculina que se encontra à esquerda poder representar o pedagogo ${ }^{64}$, embora os seus serviços pouca utilidade tivessem para uma criança que ainda não caminha.

61 Lebes gamikos ático de figuras vermelhas, c. 475-425 a.C. (Atenas, Museu do Cerâmico 2694); http://www.beazley.ox.ac.uk/record/793F153D-F212-47AC-9638-E9E23D739BC9 (BAPD 276110).

62 Para uma outra interpretação, vide Beaumont 2012: 85-86, fig. 3.27.

63 Pelike ática de figuras vermelhas, estilo do Pintor do Banho (Washing Painter), c. 430-420 a.C. (Londres, The British Museum E396); Garland 1990: 123, fig. 10; Massar 1995: 35; Beaumont 2003: 71-72; Neils \& Oakley 2003: 237 (cat. 37); Shapiro 2003: 104; Sutton 2004: 338-339 e fig. 17.9; Ferreira 2011: 78-79; Oakley 2013: 157, fig. 7.6; http:// www.beazley.ox.ac.uk/record/6B257F58-A71F-4EDD-8708-7885C598B7C2 (BAPD 215016).

64 Cf. Garland 1990: 123; Neils \& Oakley 2003: 237. 
Caso se trate do pai, foi representado como um homem maduro e o seu olhar parece dirigido para a mulher (à direita), que está concentrada no ser que começa a gatinhar, indiciando que ela pode ser a figura central da composição (Sutton 2004: 339). À semelhança das representações já discutidas, o pintor teve o cuidado de sugerir que a criança é ainda muito pequena e que se trata de um menino. Ao contrário de outras opiniões, a sua figuração não nos parece, do ponto de vista anatómico, realista, mas os seus gestos correspondem efetivamente aos de um bebé que começa a gatinhar.

Embora, como dissemos, estejamos perante um corpus bastante limitado, que a nossa seleção ainda reduziu mais, é legítimo afirmar que estas imagens dão relevo à mulher ateniense, como mãe e gestora do oikos, que vela pelas atividades domésticas, designadamente as que lidam com têxteis, surgindo normalmente sentada sobre uma cadeira de encosto. Sobre este motivo, merece destaque a observação de Eva Keuls (1993: 123-124), que vê na cadeira um "símbolo de maternidade", pois as imagens de deusas-mães, arquétipo da mãe-terra, como Deméter, são representadas também sentadas.

A criança, símbolo da descendência legítima, razão basilar do casamento, é geralmente um bebé do sexo masculino, que pode ostentar um colar de amuletos e ter brinquedos na mão. Embora haja indícios de que os pintores gregos desde cedo repararam nas linhas anatómicas do corpo infantil, como sugere o fundo de uma taça ática de figuras vermelhas, atribuída à oficina do Pintor de Sotades ${ }^{65}$, a criança é com frequência representada nestas imagens de família como um bebé com as formas físicas de um jovem ou adulto de pequenas dimensões. O observador é, assim, convidado a pensar no que representa aquele futuro elemento da polis, que, como pessoa, ainda não é um ser completo (Aristóteles, Pol. 3.1278a). Não é, portanto, de estranhar que os artistas não retratem os bebés enfaixados ${ }^{66}$, pois se o

65 Taça ática de figuras vermelhas atribuída à oficina do Pintor de Sotades, c. 470-460 a.C. (Bruxelas, Musées Royaux d'Art et d'Histoire A 890); Bioul 1989: 8-9; Keuls 1993: 110, fig. 95; Neils \& Oakley 2003: 240-241 (cat. 42); Lynch \& Papadopoulos 2006: 20-24, fig. 12; Cohen 2011: 481; http://www.beazley.ox.ac.uk/record/04223B24-E00C-4B2B-96BC-0464F4CF06A0 (BAPD 209536).

66 Sobre o costume de envolver os recém-nascidos com faixas de tecido (spargana), vide Garland 1990: 81-83, fig. 7; Beaumont 2012: 38 e fig. 2.6a, 50-52 e figs. 3.4, 3.5; Golden 2015: 13-14. 
fizessem não poderíamos conhecer o sexo da criança, um aspecto fundamental destas figurações ${ }^{67}$, mas a imagem do corpo infantil na arte grega é uma questão complexa e deve ser discutida com mais atenção.

Se outras figuras femininas podem ser escravas, familiares ou amigas, cremos que o homem, ainda que imberbe, representa o marido, o kyrios e cidadão ateniense, visto que surge envolto num manto e apoiado num bastão, sugerindo que a sua presença no aposento feminino é temporária, como se estivesse a regressar a casa ou se preparasse para sair. Vale a pena recordar a observação relevante de H. Alan Shapiro (2003: 103-104) de que são raras, na arte ateniense, as representações de interação entre pais e filhos. Quando o progenitor aparece num ambiente doméstico, como nas imagens que comentámos, é retratado mais como observador do que como participante ${ }^{68}$. Devemos sublinhar que esta presença do kyrios num cenário de família, embora muito menos atestada nas pinturas que se preservaram, dá visibilidade à importância do oikos como base fundamental da identidade cívica ateniense (cf. Osborne 1997: 32).

No que respeita ao suporte cerâmico, as imagens comentadas surgem em vasos que eram usados em casa e utilizados maioritariamente pelas mulheres ${ }^{69}$. São peças para guardar cosméticos ou jóias, para recolher água na fonte, para usar no banho nupcial. Portanto, oferecidos talvez como presente de casamento, estes vasos pintados recordavam à jovem noiva as suas obrigações para com o kyrios e a sua polis: ser mãe, ocupar-se das atividades domésticas, cuidar do oikos.

67 Para uma outra interpretação, vide Sutton 2004: 344. Cf. Keuls 1993: 73, 110; Lewis 2002: 17-19; Beaumont 2012: 52.

68 Cf. Massar 1995: 34, 37; Neils \& Oakley 2003: 237. Em nota (cf. p. 110 n. 95), H. A. Shapiro remete para uma conferência de R. Sutton, "Men in the House: Domestic Space on Attic Pottery", apresentada em 2001 no Archaeological Institute of America.

69 O facto de algumas destas peças terem sido recuperadas de sepulturas de mulheres, onde teriam sido depositadas como oferendas funerárias, como a taça de Sotades que se encontra em Bruxelas (cf. n. 65), confirma a sua associação ao mundo feminino. Cf. Beard 1991: 27; Massar 1995: 37. 


\section{REFLEXÕES FINAIS}

As imagens pintadas nos vasos gregos não tinham somente a função de deleitar o olhar ou tornar mais valioso um objeto de uso comum. Tal como a escultura e a literatura, comunicam ideias e sublinham valores, relacionam-se de forma dinâmica com o contexto histórico e cultural em que foram produzidas, com a tradição mitológica, a experiência religiosa e as práticas sociais, com outras formas de representação, reproduzindo em maior ou menor grau o discurso político e social vigente. No ensaio que dedicou à metodologia de análise da figuração de cenas da vida doméstica na cerâmica grega, Mary Beard observou, com acuidade notável, que estas imagens não constituem "a picture of, but a statement about domestic life"7o. É esta ideia básica que fundamenta as linhas de interpretação que seguimos neste trabalho.

Em resumo, este estudo centrou-se na análise de dois temas iconográficos - a missão de Triptólemo e as cenas de família - com vista a examinar o papel da pintura de vasos áticos enquanto veículo ideológico. Quanto ao primeiro, não cremos que a importância crescente dos Mistérios de Elêusis explique por si só a popularidade e manutenção de uma temática que fora tratada desde meados do século VI a.C. e continuou a ser partilhada por muitas oficinas áticas durante toda a Época Clássica. De facto, a missão de Triptólemo não alude propriamente ao ritual eleusino, mas à transmissão da cultura do cereal, um acontecimento civilizacional que Atenas reivindicou em seu benefício. No que respeita ao segundo, a nossa breve análise procurou mostrar que a seleção dos elementos iconográficos que compõem as representações de cenas de família na pintura de vasos áticos obedece a esquemas aos quais está subjacente uma ideologia que coloca a esposa no centro do oikos, esse espaço privado que, desde a lei proposta por

70 Beard 1991: 20. No importante estudo sobre a figuração das mulheres nos vasos gregos, F. Lissarrague insiste na ideia de que a função das imagens "não é representar indivíduos específicos, mas antes evocar modelos míticos ou momentos paradigmáticos da vida social." (1993: 231). A relação entre as imagens dos vasos áticos, as práticas sociais femininas e os ideais da polis ateniense é discutida em detalhe por Lessa 2010. 
Péricles, passou a ser determinante para a definição do que se entendia por cidadão ateniense.

A construção da democracia ateniense, que se tornou num modelo duradouro para a cultura política do Ocidente, é fruto de um longo e complexo processo histórico cuja abrangência deve ser examinada com recurso a diferentes metodologias de trabalho. Com o nosso estudo quisemos também mostrar que a cultura material e os documentos iconográficos, não obstante as muitas problemáticas e dúvidas, podem fornecer pistas de trabalho produtivas e constituir um contributo muito relevante para um entendimento mais completo da história política e social do mundo antigo.

\section{REFERÊNCIAS BIBLIOGRÁFICAS}

Andrewes, A. (1956), The Greek Tyrants. London.

Andrewes, A. (1982, $2^{a}$ ed.), "The Tyranny of Pisistratus", in J. Boardman \& N. G. L. Hammond (eds.), The Cambridge Ancient History. III.3: The Expansion of the Greek World, Eighth to Sixth Centuries B.C. Cambridge, 392-416.

Barringer, J. M. (2008), Art, Myth, and Ritual in Classical Greece. Cambridge.

Beard, M. (1991), "Adopting an Approach II", in T. Rasmussen and N. Spivey (eds.), Looking at Greek Vases. Cambridge, 12-35.

Beaumont, L. A. (2003), "The Changing Face of Childhood", in Neils \& Oakley 2003: 58-83.

Beaumont, L. A. (2012), Childhood in Ancient Athens: Iconography and Social History. London-New York.

Beschi, L. (1988), Lexicon Iconographicum Mythologiae Classicae (LIMC). Vol. IV. Zürich und München, s.v. Demeter.

Bioul, A.-C. (1989), Scènes de la vie quotidienne dans la Grèce antique (525-425 avant J.-C.). Bruxelles.

Blok, J. H. (2009), "Perikles' Citizenship Law: a New Perspective", Historia 58.2: 141-170.

Boardman, J. (1972), "Herakles, Peisistratos and Sons", RA 1: 57-72.

Boardman, J. (1974), Athenian Black Figure Vases. A Handbook. London.

Boardman, J. (1975a), Athenian Red Figure Vases. The Archaic Period. A Handbook. London.

Boardman, J. (1975b), "Herakles, Peisistratos, and Eleusis", JHS 95: 1-12.

Boardman, J. (1984), "Image and Politics in Sixth-Century Athens: Some Problems", in H. A. G. Brijder (ed.), Ancient Greek and Related Pottery. Amsterdam, 239-247.

Boardman, J. (1989a), Athenian Red Figure Vases. The Classical Period. A Handbook. London.

Boardman, J. (1989b), "Herakles, Peisistratos, and the Unconvinced", JHS 109: 158-159.

Boardman, J. (1991, $2^{\mathrm{a}}$ ed.), Greek Sculpture. The Classical Period. A Handbook. London.

Boardman, J. (1997), "The Bosanquet Painter", in Oakley et alii 1997: 241-248.

Boedeker, D. (2007), "The View from Eleusis. Demeter in the Persian Wars", in E. Bridges, E. Hall \& P. J. Rhodes (eds.), Cultural Responses to the Persian Wars: Antiquity to the Third Millennium. 
Oxford, 65-82.

Boedeker, D. and Raaflaub, K. A. eds. (1998), Democracy, Empire, and the Arts in Fifth-Century Athens. Cambridge.

Boegehold, A. L. (1994), "Pericles' Citizenship Law of 451/0 B.C.”, in A. L. Boegehold \& A. C. Scafuro (eds.), Athenian Identity and Civic Ideology. Baltimore, 57-66.

Bonfante, L. (1997), "Nursing Mothers in Classical Art”, in A. O. Koloski-Ostrow \& C. L. Lyons (eds.), Naked Truths. Women, Sexuality, and Gender in Classical Art and Archaeology. LondonNew York, 174-196.

Brock, R. (1994), "The Labour of Women in Classical Athens", CQ 44.2: 336-346.

Brulé, P. (2001), Les femmes grecques à l'époque classique. Paris.

Cameron, A. \& Kuhrt, A., eds. (1993, $2^{\text {a }}$ ed.), Images of Women in Antiquity. London.

Carpenter, Th. (1991), Art and Myth in Ancient Greece. London.

Castriota, D. (1992), Myth, Ethos, and Actuality: Official Art in Fifth-century B.C. Athens. Wisconsin. Clairmont, Ch. W. (1993), Classical Attic Tombstones. Kilchberg. [CAT]

Cohen, A. (2011), "Picturing Greek Families", in B. Rawson (ed.), A Companion to Families in the Greek and Roman Worlds. Chichester, West Sussex-Malden, MA, 465-487.

Cohen, A. \& Rutter, J. B., eds. (2007), Constructions of Childhood in Ancient Greece and Italy. Hesperia Suppl. 41. Princeton.

Cohen, D. (1989), "Seclusion, Separation, and the Status of Women in Classical Athens", GER 36: 3-15.

Dugas, C. (1950), "La mission de Triptolème d'après l'imagerie athénienne", Mélanges d'archéologie et d'bistoire 62.1: 7-31.

Evans, N. (2010), Civic Rites. Democracy and Religion in Ancient Athens. Berkeley.

Fantham, E. et alii (1994), Women in the Classical World. Oxford-New York.

Ferreira, J. R. (1990), "Péricles e a democracia ateniense", Euphrosyne 18: 23-38.

Ferreira, J. R. (1990), A democracia na Grécia antiga. Coimbra.

Ferreira, J. R. (2004, 2a ed.), A Grécia antiga. Sociedade e política. Lisboa.

Ferreira, J. R. \& Leão, D. F. (2010), Dez Grandes Estadistas Atenienses. Lisboa.

Ferreira, L. N. (2011), "Crianças na arte grega. Representações sociais e convenções artísticas", in C. Soares et alii (coords.), Norma E Transgressão II. Coimbra, 59-95. DOI: http://dx.doi. org/10.14195/978-989-26-0236-3_3.

Ferreira, L. N. (2013), Mobilidade poética na Grécia Antiga: uma leitura da obra de Simónides. Coimbra. DOI: http://dx.doi.org/10.14195/978-989-721-032-7.

Foley, H. P. (2003), "Mothers and Daughters", in Neils \& Oakley 2003: 112-137.

Foley, H. P., ed. (1994), The Homeric Hymn to Demeter. Translation, Commentary, and Interpretive Essays. Princeton, N. J.

Forrest, W. G. (1966), La naissance de la démocratie grecque de 800 à 400 avant Jésus-Christ. Tr. fr. J. Cathelin. Paris.

Garland, R. (1990), The Greek Way of Life: from Conception to Old Age. London.

Golden, M. (2015, 2a ed.), Children and Chilhood in Classical Athens. Baltimore.

Gould, J. (1980), "Law, Custom, and Myth: Aspects of the Social Position of Women in Classical Athens", JHS 100: 38-59.

Hawley, R. \& Levick, B. (1995), Women in Antiquity. New Assessments. London-New York.

Hayashi. T. (1992), Bedeutung und Wandel des Triptolemosbildes vom 6.-4. Jh. v. Chr.: Religionshistorische typologische Untersuchungen. Würzburg.

Iriarte, A. (2002), De Amazonas a Ciudadanos. Pretexto Ginecocrático y Patriarcado en la Grecia 
Antigua. Madrid.

Iriarte, A. (2015), "Semblanzas de semi-ciudadanías griegas. Sobre críos, ancianos y féminas", in A. Iriarte \& L. N. Ferreira (coords.), Idades e género na literatura e na arte da Grécia Antiga. Coimbra-São Paulo, 9-30. DOI: http://dx.doi.org/10.14195/978-989-26-1017-7.

Janko, R. (1982), Homer, Hesiod and the Hymns. Diachronic Development in Epic Diction. Cambridge. Just, R. (1989), Women in Athenian Law and Life. London-New York.

Keuls, E. C. (1993), The Reign of the Phallus. Sexual Politics in Ancient Athens. Berkeley.

Lacey, W. K. (1968), The Family in Classical Greece. London.

Laurens, A.-F. (1995), "Les ateliers de céramique", in Verbanck-Piérard \& Viviers 1995: 161-183.

Leão, D. F. (2003), Aristóteles. Constituição dos Atenienses. Introdução, tradução do original grego e notas. Lisboa.

Leão, D. F. (2011), "In Defense of Medea: a Legal Approach to Euripides", Epetiris 43: 9-26.

Leão, D. F. (2012), "The Myth of Autochthony, Athenian Citizenship and the Right of enktesis: A Legal Approach to Euripides' Ion", in B. Legras \& G. Thür (eds.), SYMPOSION 2011. Études d'histoire du droit grec et hellénistique (Paris, 7-10 sept. 2011). Wien, 135-153.

Leduc, C. (1993), "Como dá-la em casamento? A noiva no mundo grego (séculos IX-IV a.C.)", in Schmitt Pantel 1993: 277-347.

Lee, M. M. (2015), Body, Dress, and Identity in Ancient Greece. Cambridge.

Lessa, F. S (2010, 2a ed.), Mulheres de Atenas. Mélissa - do Gineceu à Agorá. Rio de Janeiro.

Lewis, S. (2002), The Athenian Woman. An Iconographic Handbook. London-New York.

Lissarrague, F. (1993), "A figuração das mulheres", in Schmitt Pantel 1993: 202-271.

Lloyd-Jones, H., ed. (1996), Sophocles. Fragments. Cambridge, Mass.

Lynch, K. M. \& Papadopoulos, J. K. (2006), "Sella Cacatoria: A Study of the Potty in Archaic and Classical Athens", Hesperia 75: 1-32.

MacDowell, D. M. (1989), "The oikos in Athenian law", CQ 39.1: 10-21.

Massar, N. (1995), "Images de la famille sur les vases attiques à figures rouges à l'époque classique (480-430 av. J.-C.)", Annales d'bistoire de l'art et d'archéologie 17: 27-38.

Matheson, S. B. (1994), "The Mission of Triptolemus and the Politics of Athens", GRBS 35: 345-372.

McNiven, T. J. (2007), "Behaving Like a Child: Immature Gestures in Athenian Vase Painting", in Cohen \& Rutter 2007: 85-99.

Meiggs, R. \& Lewis, D., eds. (1988), A Selection of Greek Historical Inscriptions to the End of the Fifth Century B.C. Rev. Ed. Oxford. [ML]

Mylonas, G. E. (1961), Eleusis and the Eleusinian Mysteries. Princeton, N. J.

Neer, R. T. (2002), Style and Politics in Athenian Vase-Painting: The Craft of Democracy, ca. 530-460 B.C.E. Cambridge.

Neils, J. \& Oakley, J. H., eds. (2003), Coming of Age in Ancient Greece. Images of Childhood from the Classical Past. New Haven-London.

Oakley, J. H. (2000), "Some 'Other' Members of the Athenian Household: Maids and Their Mistresses in Fifth-Century Athenian Art", in B. Cohen (ed.), Not the Classical Ideal. Athens and the Construction of the Other in Greek Art. Leiden, 227-247.

Oakley, J. H. (2013), "Children in Archaic and Classical Greek Art: a Survey", in J. E. Grubbs, T. Parkin \& R. Bell (eds.), The Oxford Handbook of Childhood and Education in the Classical World. Oxford, 147-171.

Oakley, J. H. \& Sinos, R. H. (1993), The Wedding in Ancient Athens. Madison, Wisconsin.

Oakley, J. H., Coulson, W. D. E. \& Palagia, O., eds. (1997), Athenian Potters and Painters: The Conference Proceedings. Exeter. 
Osborne, R. (1997), "Law, the Democratic Citizen and the Representation of Women in Classical Athens", PEP 155: 3-33.

Parke, H. W. (1977), Festivals of the Athenians. London.

Patterson, C. (1981), Pericles' Citizenship Law of 451/50 B.C. Salem, N.H.

Pearson, A. C., ed. (1917, repr. 1963), The Fragments of Sophocles. Vol. I. Edited with Additional Notes from the Papers of Sir R. C. Jebb \& W. G. Headlam. Cambridge.

Pomeroy, S. B. (1995, 1975), Goddesses, Whores, Wives, and Slaves. Women in Classical Antiquity. With a new preface by the Author. New York.

Powell, A. (2001), "Citizen Women of Athens", in Athens and Sparta. Constructing Greek Political and Social History from 478 BC. London-New York, 348-403.

Radt, S., ed. (1999), Tragicorum Graecorum Fragmenta (TrGF). Vol. IV: Sophocles. Editio correctior et addendis aucta. Göttingen. [Radt]

Raubitschek, A. E. \& Raubitschek, I. K. (1982), "The Mission of Triptolemos", in Studies in Athenian Architecture, Sculpture and Topography Presented to Homer A. Thompson, Hesperia: Suppl. 20: 109-117 = The School of Hellas. Essays on Greek History, Archaeology, and Literature, ed. by D. Obbink \& P. A. Vander Waerdt. New York-Oxford, 1991, 229-238.

Rhodes, P. J. (1993, $2^{\text {a }}$ ed.), A Commentary on the Aristotelian Athenaion Politeia. Oxford.

Richardson, N. J., ed. (1974), The Homeric Hymn to Demeter. Oxford.

Robertson, M. (1992), The Art of Vase-Painting in Classical Athens. Cambridge.

Rocha Pereira, M. H. (2009, 10ª ed.), Hélade. Antologia da Cultura Grega. Lisboa.

Rodrigues, N. S. (2008), "O trigo como metáfora da vida e da morte na Antiguidade Clássica", Máthesis 17: 97-106.

Schmitt Pantel, P. (2016), Une histoire personnelle des mythes grecs. Paris.

Schmitt Pantel, P., dir. (1993), História das mulberes no Ocidente. Vol. 1. A Antiguidade. Trad. port. com rev. científica de M. H. da Cruz Coelho et alii. Porto.

Schwarz, G. (1997), Lexicon Iconographicum Mythologiae Classicae (LIMC). Vol. VIII. Zürich und Düsseldorf, s.v. Triptolemos.

Shapiro, H. A. (1989), Art and Cult under the Tyrants in Athens. Mainz am Rhein.

Shapiro, H. A. (1995), "Les rhapsodes aux Panathénées et la céramique à Athènes à l'époque archaïque", in Verbanck-Piérard \& Viviers 1995: 127-137.

Shapiro, H. A. (2003), "Fathers and Sons, Men and Boys", in Neils \& Oakley 2003: 84-111.

Simon, E. (1997), "Eleusis in Athenian Vase-Painting: New Literature and Some Suggestions", in Oakley et alii 1997: 97-108.

Stadter, Ph. A. (1989), A Commentary on Plutarch's Pericles. Chapel Hill-London.

Sutton Jr., R. F. (2004), "Family Portraits: Recognizing the oikos on Attic Red-Figure Pottery", in A. P. Chapin (ed.), XAPIS: Essays in Honor of Sara A. Immerwahr. Hesperia Suppl. 33: 327-350.

Verbanck-Piérard, A. \& Viviers, D., eds. (1995), Culture et cité: l'avènement d'Athènes à l'époque archä̈que. Bruxelles.

West, M. L. (2003), Homeric Hymns, Homeric Apocrypha, Lives of Homer. Cambridge, Mass.

Williams, D. (1993), "Women on Athenian Vases: Problems of Interpretation", in Cameron \& Kuhrt 1993: 92-106. 